\title{
Pemahaman Konsep Tauhid Asas Keharmonian Kepelbagaian Agama
}

\author{
The Understanding of the Concept of Tawheed as the Basis \\ for Harmonious Religious Plurality
}

\author{
NUR FARHANA ABDUL RAHMAN ${ }^{1}$
}

\begin{abstract}
Efforts in forming harmonious existence among religious believers have produced two important responses and approaches as reaction to religious diversity. The first type views religious diversity as a need for implementing active tolerance attitude among religious believers although this does not proceed to relativism and the second type of view acknowledges the unity of religious truths. Essentially, Islam has many models and systems in dealing with religious diversity. In evidence, the essence of Islamic teachings is the obligation of Muslims to act in justice and peaceful to all human beings regardless of their religious beliefs. This has also been described in Al-Faruqi's discourse on meta-religion. However, the Islamic teachings that emphasize on respect to other religious believers should not exceed the basic tenets of Islamic creed and faith. This study found that the concept of tawhid in Islam can be a strong argument in cultivating tolerance and harmony among people of different religions.
\end{abstract}

Keywords: tawhid, religious harmony, Islam.

Perkataan 'tauhid', secara umumnya menggambarkan lafaz tradisi yang penting dan menjadi pegangan akidah khususnya bagi umat Islam iaitu merasa yakin dan saksi bahawa 'Tiada Tuhan yang disembah melainkan Allah'. Syahadah dan Muslim merupakan satu perkaitan yang amat padu tanpa boleh dipisahkan. Lafaz saksi ini merupakan satu lafaz wajib dan menjadi asas kepada semua kepercayaan dan pelaksanaan dalam kehidupan seharian umat Muslim. Penegasan terhadap konsep tauhid ini banyak dijelaskan dan diungkapkan di dalam sumber-sumber Islam terutama dalam menyatakan tauhid sebagai matlamat penciptaan manusia seperti yang disebut dalam firman Allah s.w.t yang bermaksud: "Kami tidak mencipta jin dan manusia melainkan untuk menyembah dan beribadat kepada $\mathrm{Ku}$ " (51:56) dan diperkukuhkan lagi dengan firman Allah yang lain, "Dan hendaklah kamu beribadat kepada Allah dan janganlah kamu sekutukan-Nya dengan sesuatu apa jua" (4:36). Justeru itu, dalam konsep tauhid, beberapa tema utama yang semestinya menjadi rukun termasuklah tentang kewujudan Pencipta dan makhluk, kewujudan pengiktirafan kepada Yang Esa, kewujudan penolakan terhadap sekutu, kewujudan konsep keimanan, kebenaran, kebaikan dan amanah.

\footnotetext{
${ }^{1}$ Nur Farhana Abdul Rahman, Ph.D., Lecturer at Dept. of Theology and Philosophy, Faculty of Islamic Studies, Universiti Kebangsaan Malaysia, 43600 BANGI, Selangor, Malaysia, email: nfarhana@ukm.edu.my.
} 


\section{Tauhid dan Kepelbagaian Agama}

Konsep tauhid merupakan satu konsep utama yang menjadi asas dalam semua sudut pandangan dan seluruh aspek kehidupan Muslim. Tauhid merupakan satu asas keimanan yang ditekankan dalam Islam. Tauhid yang berasal dari kalimah Arab tawhid (توحيد) merupakan satu konsep yang melambangkan kepercayaan monoteisme dalam Islam yang mempercayai bahawa Tuhan itu hanya satu. Dalam bahasa Arab, tauhid bermaksud penyatuan dan di dalam agama Islam ia dikhususkan kepada penyatuan dengan Allah. Kata lawan bagi konsep tauhid ini ialah penyekutuan atau dalam erti kata lain boleh difahami sebagai penduaan, kesyirikan atau secara khususnya penyembahan selain Allah.

Dari sudut bahasa, tauhid bermaksud mengetahui dengan sebenarnya Allah itu Wujud, Ada dan Esa. Menurut istilah, tauhid ialah satu ilmu yang menjelaskan tentang wujud Allah dan sifat-sifatnya, pembuktian terhadap kerasulan para rasul dan sifat-sifatnya dan pembahasan terhadap perkara-perkara sam iyyat dan akidah dengan berasaskan kepada sumber-sumber Islam terutamanya al-Quran dan Hadis. Di dalam ajaran Islam, kalimah La ilaha illallah bermaksud 'Tidak ada Tuhan selain Allah' merupakan kalimah tauhid yang asas. Kalimah ini menunjukkan bahawa manusia tidak ada tempat bersandar, berlindung dan berharap kecuali Allah, tidak ada yang menghidupkan dan mematikan, tiada yang memberi dan menolak melainkan Allah. Zahirnya syariat menyuruh manusia berusaha beramal, sedang hakikatnya syariat melarang mereka menyandarkan diri pada amal usaha itu supaya tetap bersandar pada kurnia Allah.

Penegasan terhadap konsep tauhid ini banyak dijelaskan dan diungkapkan di dalam sumber-sumber Islam terutama dalam menyatakan tauhid sebagai matlamat penciptaan manusia seperti yang disebut dalam firman Allah yang bermaksud: "Aku tidak mencipta jin dan manusia melainkan untuk menyembah dan beribadat kepada-Ku" (51:56) dan diperkukuhkan lagi dengan firman Allah yang lain dengan bermaksud: "Dan hendaklah kamu beribadat kepada Allah dan janganlah kamu sekutukan-Nya dengan sesuatu apa jua" (4:36).

Dalam konteks tauhid yang sebenar, penyerahan dan pengakuan kepada Tuhan yang Maha Esa sangat ditegaskan. Menurut al-Attas (1995: 53-55), pengakuan kepada Tuhan yang Maha Esa dan sikap pasrah kepada Tuhan ini hanyalah dikira ke atas penyerahan dan tauhid yang ikhlas. Al-Quran menjelaskan terdapat dua bentuk penyerahan terhadap Allah (3:83) iaitu pengakuan yang ikhlas (sukarela) dan yang lainnya adalah pengakuan secara terpaksa atau tidak sukarela. Al-Attas menegaskan bahawa The Real Submission adalah yang ikhlas dan memberi ketaatan kepada hukum-hukum-Nya)(4:125). Justeru dalam konteks ini, pengakuan iblis tidak dianggap sebagai tauhid yang murni kerana walaupun iblis menyembah Tuhan namun ia tidak secara ikhlas dan dipengaruhi dengan kesombongan, tiada ketaatan dan pemberontakan lalu ia dihukum kufr.

Namun begitu, tauhid bukanlah sekadar ucapan 'La ilaha illallah', walaupun ucapan tersebut merupakan sebahagian daripadanya tetapi tauhid itu adalah nama untuk pengertian yang agung dan ucapan yang mempunyai erti yang besar, lebih besar dari semua pengertian. Tauhid ialah pembebasan terhadap penyembahan kepada semua yang bukan kepada Allah dan penerimaan dengan hati serta peribadatan kepada Allah semata-mata.

\section{Kepelbagaian Agama}

Secara azali, dalam agama Islam telah terdapat contoh dan aturan yang telah dibekalkan dalam menghadapi kepelbagaian ini. Buktinya, dalam inti sari ajaran Islam itu sendiri wujudnya tuntutan kepada umat Islam supaya sentiasa berlaku adil dan damai sesama 


\section{Vol. 1: (June.) 2012}

semua umat manusia. Hal ini dapat dilihat dengan jelas sama ada dari tuntutan Allah yang disampaikan melalui al-Quran, panduan dari Sunah nabi, teladan dari kisah dan situasi yang berlaku pada zaman para anbia, sahabat dan sebagainya. Dalam konteks ini, perlaksanaan toleransi merupakan perkara utama yang sangat ditekankan dalam ajaran Islam sebagai langkah damai untuk hidup bersama-sama dengan agama lain. Hal ini juga secara tidak langsung menunjukkan bahawa Islam mengakui dan menghormati kewujudan agamaagama lain.

Dari sudut etimologi, kepelbagaian (plurality) membawa maksud plural ialah jamak atau gambaran yang menunjukkan perkara lebih daripada satu (Kamus Dewan 2005: 590) (menunjukkan satu aliran atau fahaman). Pluralisme pula bermaksud keadaan yang majmuk, kemajmukan (Kamus Dewan 2005: 1219). Menurut catatan Lorens (1996: 853$855)$, terdapat pelbagai ciri atau definisi yang menjelaskan mengenai kepelbagaian. Namun dalam penulisan ini, antara ciri utama yang mudah difahami ialah pluralisme merupakan satu realiti fundamental yang bersifat jamak berbeza dengan dualisme (fahaman yang menyatakan bahawa realiti fundamental ada dua) dan monoteisme (fahaman yang menyatakan bahawa realiti fundamental hanyalah satu). Selaras dengan hal ini, Rescher (1993: 2) menekankan dua perkara utama dalam menerima dan menjayakan usaha damai yang sebenar iaitu menerima kepelbagaian dan bertoleransi di atas ketidaksefahaman.

Jika dilihat dalam konteks falsafah pula, kepelbagaian dijelaskan dengan istilah pluralisme. Plural adalah kepelbagaian dan isme membawa maksud aliran. Maka pluralisme dijelaskan sebagai satu usaha membenarkan falsafah keberagaman dengan menegaskan bahawa semua kebenaran bersifat relatif dan menganggap semua keyakinan ahli falsafah dan agama dalam pengertian relativisme murni, sebagai pendapat-pendapat peribadi yang mempunyai nilai yang sama (Lorens 1996: 853-855). Namun begitu, perlu diingat bahawa apa yang ditekankan ialah penghormatan yang diberikan terhadap penganut agama-agama lain mestilah dilakukan dengan sebaiknya selagi tidak melanggar asas akidah, tauhid dan keimanan Islam. Dalam erti kata lain, usaha damai yang dianjurkan dalam Islam menjurus kepada semangat toleransi terhadap penganut dan agama-agama lain tanpa menjejaskan keimanan individu Muslim itu sendiri.

Tulisan mengetengahkan beberapa faktor utama yang menyebabkan kepelbagaian itu wujud. Faktor utama yang tidak dapat dinafikan adalah kepelbagaian adalah fitrah kejadian alam dan makhluk-Nya. Sebagai umat Islam, fitrah wujudnya kepelbagaian ini telah dijelaskan dengan lebih awal khususnya dalam di al-Quran yang mana bertujuan untuk menghasilkan kebaikan. Sebagai contoh, terdapat suruhan dan perintah yang jelas dari Allah yang menekankan kepelbagaian agama yang diturunkan adalah satu rahmat dan perlu diiktiraf. Antaranya seperti firman Allah yang bermaksud: "Kami jadikan (tetapkan) suatu syariat dan jalan agama (yang wajib diikuti oleh masing-masing), dan kalau sekiranya Allah menghendaki nescaya Ia menjadikan kamu satu umat (yang bersatu dalam agama yang satu), tetapi Ia hendak menguji kamu (dalam menjalankan) apa yang telah disampaikan kepada kamu. Oleh kerana itu berlumba-lumbalah kamu membuat kebaikan (beriman dan beramal soleh)" (5:48) dan firman Allah yang bermaksud: "Wahai umat manusia! Sesungguhnya Kami telah menciptakan kamu dari lelaki dan perempuan, dan Kami telah menjadikan kamu berbagai bangsa dan bersuku puak, supaya kamu berkenal-kenalan (dan beramah mesra antara satu dengan yang lain). Sesungguhnya semulia-mulia kamu di sisi Allah ialah orang yang lebih taqwa di antara kamu, (bukan yang lebih keturunan atau bangsanya). Sesungguhnya Allah Maha Mengetahui, lagi Maha mendalam pengetahuan-Nya (akan keadaan dan amalan kamu)" (49:13).

Ayat-ayat di atas menjelaskan bahawa manusia dijadikan dengan tujuan untuk saling berkenalan bahkan dituntut untuk saling bekerjasama dalam melakukan berbagai 
kebaikan. Malah tuntutan ini diperkukuhkan lagi dengan suruhan Allah yang menyuruh perbincangan atau teguran terhadap agama-agama ini dijalankan dengan baik dan damai. Seperti firman Allah yang bermaksud: "Serulah ke jalan Tuhanmu (Wahai Muhammad) dengan hikmat kebijaksanaan dan nasihat pengajaran yang baik, dan berbahaslah dengan mereka (yang Engkau serukan itu) dengan cara yang lebih baik" (16:125) dan firman Allah yang bermaksud: "Dan janganlah kamu berbahas dengan Ahli Kitab melainkan dengan cara yang lebih baik" (29: 46). Ayat-ayat ini membuktikan Allah juga menuntut untuk berurusan dengan kepelbagaian ini dalam keadaan yang baik sama ada dalam konteks dakwah mahupun urusan seharian.

Selain itu tidak dinafikan wujudnya faktor-faktor alami yang mendorong wujudnya kepelbagaian dalam sesuatu kawasan antaranya seperti faktor migrasi dan tuntutan globalisasi. Hal ini dijelaskan bahawa situasi seperti peperangan, kemiskinan dan pencarian ilmu merupakan antara punca utama muncul dan wujud migrasi dalam sesuatu negara. Pada abad yang lalu, migrasi berpunca dari kemiskinan lalu berpindah ke negara yang mempunyai ekonomi yang lebih stabil dianggap sebagai penyelesaian bagi menambah baik ekonomi sesebuah keluarga mahupun individu. Situasi ini turut disebabkan oleh faktor peperangan dan penjajahan. Sebagai contoh, migrasi bangsa-bangsa lain ke Tanah Melayu khususnya India dan Cina sama ada dilakukan kerana kesempitan ekonomi atau kerana penjajahan ini akhirnya menyebabkan muncul pelbagai bangsa di Malaysia. Hal yang sama juga berlakunya di seluruh dunia seperti, akibat penindasan yang berlaku di Chechnya menyebabkan penduduk Chechnya turut berhijrah dan menetap di negara-negara lain seperti di Arab, United Kingdom dan Malaysia. Malah, dalam beberapa abad yang terkemudian, faktor berlakunya migrasi ini berubah kepada pencarian ilmu dan pekerjaan yang lebih bertaraf antarabangsa. Hal ini dilihat secara positif khususnya dalam membina pengalaman dan jaringan ilmu pengetahuan yang lebih luas dan terkini.

Dalam konteks masa kini, tuntutan globalisasi turut mengambil peranan menjadi pendorong wujudnya kepelbagaian dalam sesuatu kawasan. Global menurut Kamus Dewan (2005) bermaksud dunia seluruhnya. Globalisasi secara umumnya boleh difahami sebagai pemecahan sempadan dunia menjadikan dunia sebagai satu perkampungan masyarakat tanpa sempadan. Sebagai contoh, sejajar dengan globalisasi yang berlaku pada abad ini, sesuatu tempat atau kawasan itu tidak semestinya didiami oleh satu penganut satu-satu agama sahaja (tidak semestinya di Amerika semua adalah bukan Muslim, atau di Arab Saudi semua penduduk menganuti agama Islam dan sebagainya) malah sistem komunikasi dan pengurusan dalam kehidupan hari ini juga melibatkan dan merangkumi semua jenis manusia yang terdiri dari pelbagai penganut agama. Justeru berdasarkan contoh-contoh situasi kepelbagaian yang muncul ini menunjukkan bahawa kepelbagaian telah mengambil tempat di muka bumi ini sehingga tiap satu dari ahli di dalamnya akan meninggalkan kesan kepada sistem kehidupan masa kini.

\section{Tauhid Asas Pengiktirafan Kepelbagaian Agama Sebagai Rahmat Tuhan Yang Esa}

Konsep ketauhidan secara asasnya merangkumi pengakuan akan keesaan dan kekuasaan Tuhan dalam semua perkara termasuk mengakui kekuasaan-Nya dalam mewujudkan agama-agama yang pelbagai. Tidak dapat dinafikan bahawa sememangnya sejak dari awal kemunculan Islam, turunnya wahyu-wahyu Allah yang telah menjelaskan wujudnya pelbagai agama-agama lain di samping Islam. Pengiktirafan terhadap kepelbagaian khususnya dalam agama dijelaskan melalui firman- firman Allah berikut yang bermaksud: 


\section{Vol. 1: (June.) 2012}

Sesungguhnya orang-orang yang beriman, dan orang-orang Yahudi dan orang-orang Nasara (Nasrani), dan orang-orang Sabi in, sesiapa di antara mereka itu beriman kepada Allah dan (beriman kepada) hari akhirat serta beramal soleh, maka bagi mereka pahala balasannya di sisi Tuhan mereka, dan tidak ada kebimbangan (dari berlakunya kejadian yang tidak baik) kepada mereka, dan mereka pula tidak akan berdukacita (2:62).

Dan kalaulah Tuhan mu (Wahai Muhammad) menghendaki, tentulah Ia menjadikan umat manusia semuanya menurut agama yang satu. (tetapi Ia tidak berbuat demikian) dan kerana itulah mereka terus-menerus berselisih (11:118).

Berdasarkan ayat-ayat di atas, menunjukkan bahawa panduan menghadapi kepelbagaian agama telah dinyatakan dalam ajaran Islam khususnya dalam konteks pengiktirafan kepelbagaian agama sebagai rahmat Tuhan. Dalam hal ini, perlu diimani bahawa Tuhan tidak meninggalkan pluralisme (kepelbagaian) ini sebagai satu masalah kepada manusia. Penyelesaian ataupun jalan untuk menghadapi kepelbagaian khususnya dalam agama-agama juga turut dinyatakan dengan jelas seperti melalui tuntutan toleransi. Dalam hal ini toleransi agama yang sebenarnya hanya wujud ketika manusia belajar menghargai keyakinan-keyakinan agama yang mereka anggap salah. Akan tetapi bukanlah bertindak merelatif perbezaan tetapi hanyalah membentuk kemahuan untuk hidup dalam perbezaan yang sememangnya wujud.

Bertolak dari hujah ini, wujudnya kepelbagaian agama di dalam alam ini tidak dapat dinafikan kerana ia merupakan hakikat penciptaan atau Sunnatullah akan makhluk-Nya. Kepelbagaian ini adalah satu rahmat Tuhan supaya manusia dapat berkenal-kenal antara satu sama lain bukan untuk peperangan, pergaduhan atau penafian kewujudan agama lain. Dalam erti kata lain, hujah ini membuktikan bahawa pluralisme agama adalah satu pengiktirafan kewujudan agama-agama hendaklah dilaksanakan melalui pelaksanaan toleransi aktif. Seperti setiap penganut agama bersama-sama bergotong royong dalam membina rumah ibadah agama, bersatu padu dalam menghadapi musuh yang menentang negara yang mereka sama-sama duduki, berdialog antara agama dan seumpamanya. Hal ini turut dituntut dalam ajaran Islam. Ini kerana, kepelbagaian agama ini harus dihormati dengan ikhlas. Ia tidak perlu kepada perlaksanaan pertukaran agama dan tidak juga membawa kepada pengiktirafan persamaan agama-agama atau agama lain adalah samasama benar.

\section{Tauhid Asas Kesatuan Wahyu Tuhan, Kenabian dan Kebenaran}

Selaras dengan konsep tauhid yang dijelaskan sebelum ini, tidak dapat dinafikan wujudnya satu kuasa atau kewujudan yang Maha Agung dan Maha Berkuasa. Dia adalah Tuhan yang Maha Esa, Maha Sempurna, Maha Baik dan Maha Adil. Bertolak dari sifat dan kekuasaan Tuhan ini, dijelaskan bahawa Tuhan Yang Satu ini tidak akan meninggalkan makhlukmakhluk-Nya dalam kegelapan dan kejahilan. Dalam hal ini, perkara utama yang perlu ditegaskan ialah dalam setiap zaman Tuhan akan menurunkan dan membekalkan makhlukNya panduan dan petunjuk bagi memandu manusia menjalani kehidupan. Hujah ini dikukuhkan lagi dengan memetik firman Allah yang bermaksud:

(Ingatlah) ketika Tuhannya berfirman kepadanya:"Berserahlah diri (kepada Aku Wahai Ibrahim)!" Nabi Ibrahim menjawab: "Aku berserah diri (tunduk 
taat) kepada Tuhan yang memelihara dan mentadbirkan sekalian alam. Dan Nabi Ibrahim pun berwasiat dengan agama itu kepada anak-anaknya, dan (demikian juga nabi) Yaakub (berwasiat kepada anak-anaknya) katanya: "Wahai anak-anakku! Sesungguhnya Allah telah memilih Agama (Islam) ini menjadi ikutan kamu, maka janganlah kamu mati melainkan kamu dalam keadaan Islam. (Demikianlah wasiat Nabi Yaakub, bukan sebagaimana yang kamu katakan itu Wahai orang-orang Yahudi)! kamu tiada hadir ketika Nabi Yaakub hampir mati, ketika ia berkata kepada anak-anaknya: "Apakah yang kamu akan sembah sesudah aku mati?" mereka menjawab: "Kami menyembah Tuhanmu dan Tuhan datuk nenekmu Ibrahim dan Ismail dan Ishak, iaitu Tuhan Yang Maha Esa, dan kepada-Nyalah sahaja kami berserah diri (dengan penuh iman)" (2:131-133).

Katakanlah (Wahai Muhammad): "Kami beriman kepada Allah, dan kepada apa yang telah diturunkan kepada kami, dan kepada apa yang telah diturunkan kepada nabi-nabi: Ibrahim, dan Ismail, dan Ishaq, dan Yaakub, dan keturunannya, dan kepada apa yang telah diberikan kepada nabi-nabi: Musa dan Isa, dan sekalian nabi-nabi dari Tuhan mereka. Kami tidak membeza-bezakan seseorang pun di antara mereka, dan kepada Allah jualah kami berserah diri (Islam)" (3:84).

Selaras dengan penjelasan ini menunjukkan bahawa ajaran yang dibawa oleh semua nabi terdahulu kepada umat mereka dan ia harus diterima sebagai agama dan semua ajaran dan wahyu yang disampaikan oleh para nabi ini adalah dari sumber yang sama iaitu Tuhan yang Maha Esa. Malah apa yang perlu ditegaskan lagi adalah, setiap agama harus berusaha melengkapi agama yang lain dan dalam hal ini semua agama yang diwahyukan dari Allah khususnya agama yang dibawa oleh Nabi Muhammad s.a.w dan sering didakwa sebagai penyempurna agama-agama sebelumnya seharusnya menunjukkan contoh yang terbaik dalam usaha untuk melengkapi malah semua agama yang diwahyukan ini tidak boleh bersaing sesama sendiri. Dalam erti kata lain, sesebuah agama syurga (iaitu yang diwahyukan dari Tuhan) tidak berhak untuk bersaing dengan agama-agama syurga yang lain, tapi apa yang sepatutnya adalah bertoleransi dengan agama-agama syurga yang lain (Adnan 1994: 88).

Kesemua agama syurga di dalam dunia ini asalnya merupakan satu cahaya yang diturunkan dari Tuhan yang sama. Dalam erti kata lain perbezaan berlaku dari sudut pelaksanaan kerana ia ditanggapi oleh kepelbagaian manusia dari latar belakang kepercayaan, adat, dan tatatertib kehidupan yang berbeza.

\section{Tauhid Asas Kesatuan Ummah}

Kekeliruan dalam memahami kepelbagaian agama ini sering terjadi khususnya dalam menyatakan; pertama sekali ialah semua agama ini wujud dan keduanya ialah semua agama ini benar. Dalam hal ini umat Islam perlu ingat dan berwaspada bahawa bagi idea yang pertama, ia menuntut supaya mengakui kewujudan agama lain termasuk mengakui kewujudan organisasi agama mereka dan sistem kepercayaan agama tersebut. Bagi idea kedua pula, idea ini menuntut kepada mengakui kebenaran agama lain, termasuk kebenaran sistem kepercayaan dan apa sahaja yang berkaitan dengan agama tersebut. Idea yang pertama membawa kepada pengiktirafan atau pengakuan kewujudan pelbagai agama di atas muka bumi sehingga menuntut kepada pelaksanaan toleransi aktif. Dalam kelompok 


\section{Vol. 1: (June.) 2012}

ini, wujudnya usaha untuk mencari persamaan antara agama sebagai landasan untuk bertoleransi. Namun perbezaan yang timbul antara agama-agama tidak dinafikan dan tidak bertindak merelatifkan kemutlakan agama-agama yang wujud. Namun begitu bagi idea yang kedua, fahaman ini mencetuskan pluralisme agama kerana idea ini menjurus kepada pengiktirafan akan kesatuan kebenaran semua agama. Hasilnya, wujud usaha mencari persamaan antara agama yang melampau sehingga cuba menyamakan semua agama sehingga menafikan perbezaan yang timbul. Hal ini sekaligus merelatifkan kemutlakan agama dengan didasari kepada pegangan semua agama benar dan satu.

Apa yang berlaku adalah kedua-dua idea ini mempunyai perbezaan yang ketara. Dalam erti kata lain kemajmukan agama tidak membawa maksud kesatuan agama atau kesetaraan (penyamaan) iman umat beragama. Bagi fahaman agama yang pertama, penyelesaian yang diberikan adalah membawa kepada penghormatan, toleransi, berbuat baik, bermujamalah dan berbaik sangka dengan penganut agama-agama lain tanpa membuat persamaan atau menafikan perbezaan dalam ajaran agama. Dalam erti kata lain, fokus yang diberikan berdiri di atas kata kunci toleransi penganut agama dengan mengakui dan menghormati perbezaan yang wujud dalam identiti agama masing. Akan tetapi, bagi fahaman pluralisme agama bagi idea kedua, fahaman yang diberikan atau perjuangan yang dilaksanakan lebih kepada perjuangan penyamaan agama-agama (Hick 2005) sehingga membawa kepada penafian perbezaan antara agama, pentafsiran semula teks-teks agama melalui kaedah pentafsiran yang lebih berbentuk logik dan rasional, pengubahsuaian hukum-hukum fikah yang qat’iy, dan menimbulkan kontroversi yang pelbagai. Hal ini secara tidak langsung turut membawa maksud bahawa fahaman pluralisme agama sebagaimana dalam bahagian yang kedua tidak pernah dinyatakan dengan jelas dalam agama Islam malah turut mendapat kritikan dari kelompok-kelompok 'agamawan' (kelompok yang mempunyai autoriti dalam agama seperti para ulama, para rahib dan sebagainya) dalam agama-agama lain.Justeru itu agama Islam mengiktiraf kepelbagaian agama bukan pluralisme agama.

Menurut al-Faruqi, dalam menanggapi kepelbagaian agama ini, pendekatan agama perlu dilihat dari dua sudut pandang iaitu agama sebagai meta religion dan agama sebagai historical religion. Meta religion merupakan agama asal yang diturunkan oleh Tuhan manakala historical religion merupakan agama asal yang telah bercampur dan diubahsuai oleh sesuatu bangsa, zaman, tempat, sejarah, kebudayaan, corak kepimpinan dan yang seumpamanya.

Dalam konteks ini, al-Faruqi mendakwa bahawa prinsip meta religion selaras dengan prinsip al-Quran dalam menghadapi kepelbagaian agama. Menurut al-Faruqi, keselarasan ini dapat dilihat melalui prinsip di dalam meta religion yang menerima bahawa semua agama adalah diwahyukan Tuhan. Walau bagaimanapun diakui adanya kemungkinan bahawa agama yang asal ini akan berubah kepada historical religion apabila bercampur aduk dengan sejarah dan budaya (al-Faruqi 1986). Meta religion ini juga menganggap bahawa idea kesatuan wahyu dan kenabian merupakan idea atau fenomena biasa yang berlaku atau diterima dalam setiap agama. Dalam erti kata lain, tidak dapat dinafikan bahawa setiap manusia telah diwahyukan atau diutus nabi kepada mereka supaya dapat mengajar dan membawa manusia mengenai agama dan mengenal Tuhan. Ini selaras dengan firman-firman Allah (35:24; 25:51 \& 16:3). Kesatuan wahyu ini juga menunjukkan kekuasaan Tuhan Yang Maha Adil, Pencipta semua makhluk yang tidak akan hanya membantu sebahagian makhluk dan menafikan sebahagian yang lain. Dalam hal ini, alFaruqi mencatatkan bahawa (1998: 135): "Revelation therefore, is not a privilege peculiar to the Muslims, but a blessing granted to humankind. Since revelation from God's transcendence 
in that revelation being an act of mercy, it would not be consonant with divine transcendence to give it some and deny it to others".

Justeru itu, semua umat manusia menerima pesanan dan panduan dari Tuhan ini. Bertolak dari konsep ini, al-Faruqi seterusnya menjelaskan bahawa sememangnya diakui bahawa semua agama ini sama-sama benar dan sama-sama betul kerana ia berasaskan sumber yang sama. Namun kesatuan kebenaran ini hanya diakui dalam konteks agamaagama asal (al-Din al-Fitrah) yang diturunkan kepada manusia. Ini kerana, apabila telah diturunkan kepada manusia terdapat beberapa unsur atau perkembangan agama yang berlaku di luar konsep al-Din al-Fitrah, maka agama akan bertukar kepada historical religion. Sebagai contoh, al-Faruqi menjelaskan bahawa ketaksuban penganut Yahudi dalam menggambarkan Tuhan telah memilih bangsa mereka sebagai bangsa pilihan untuk diselamatkan adalah satu dari historical Jews religion, begitu juga hal yang sama berlaku kepada Kristian apabila mula menimbulkan kepercayaan Trinity dalam agama mereka maka ia menyebabkan wujudnya historical Christian religion. Melalui historicals religion ini, akhirnya membawa kepada wujudnya perbezaan dalam agama-agama dan perbezaan ini tidak dapat dinafikan lagi khususnya pada masa kini dan tidak boleh disatukan. Ini kerana terdapat unsur-unsur pengubahsuaian yang didasarkan kepada sejarah dan peradaban sesuatu kaum.

Selaras dengan hal ini, al-Faruqi iturut menjelaskan bahawa Islam merupakan salah satu dari agama Abrahamic Religion iaitu Yahudi, Nasrani dan Islam. Namun al-Faruqi turut menegaskan bahawa situasi ini (Islam sebagai Abrahamic Religion) menjelaskan bahawa penghormatan yang diberikan kepada Yahudi dan Kristian bukanlah semata- mata bersifat mujamalah diplomatik tetapi ia adalah penghormatan sebenar terhadap asal kedua agama tersebut kerana Islam tidak melihat kedua-dua agama ini sebagai asing dari teologi Islam sendiri malah keduanya adalah satu rumpun yang satu dan dengan sebab ini Islam turut mewajibkan penganutnya untuk bertoleransi dan hidup berdamai dengan penganut keduadua agama ini. Namun perlu diingat pengiktirafan sama hanya diberikan kepada agama asal meta religion bukan kepada historical religion kerana telah mengandungi pengubahsuaian yang menyebabkan wujudnya perbezaan yang tidak dapat dinafikan.

Dari perspektif tauhid ini turut menjelaskan kesamaan manusia di hadapan Tuhan dan membuktikan persamaan kedudukan antara penganut agama khususnya semua yang diasaskan dari al-Din al-Hanif atau dari Abrahamic Religion. Berdasarkan penjelasan dari ini, pengiktirafan terhadap kewujudan agama-agama lain dan pelaksanaan toleransi yang sewajarnya sememangnya menjadi tuntutan utama. Secara asasnya, ini juga adalah asas kepercayaan dan tuntutan dalam umat Islam yang telah mengiktiraf dan menghormati kewujudan agama lain. Hal ini tidak dapat dinafikan kerana ia turut menjadi amalan yang dilakukan oleh Rasulullah s.a.w khususnya dalam perjanjian Piagam Madinah. Namun perlu ditegaskan bahawa dari perspektif Islam, manusia diajar supaya beriman dan menyembah Allah sahaja dan bukan tuhan-tuhan yang lain selain Allah (21:25; 7:59, 73 \& 112:1-4). Selain itu perlu juga ditegaskan bahawa semua manusia diciptakan oleh Tuhan yang satu. Tuhan sememangnya telah mengutus para (nabi-nabi) para anbia dan rasul-Nya dari pelbagai bangsa dan bahasa sebelum kedatangan nabi Muhammad (16:36; 10:71-72; 12:101, 84; 24:44 \& 5:44). Tetapi, setelah ajaran-ajaran sebelum ini banyak dipalsukan dan diubahsuai oleh penganutnya maka ajaran Islam yang sebenar ini telah dilengkapkan oleh Allah melalui utusan Nabi Muhammad s.a.w. dan tidak perlu lagi nabi dan rasul selepas beliau kerana nabi Muhammad adalah penyempurna dan membenarkan lagi agama terdahulu dan ajarannya merupakan ajaran Islam yang terakhir (5:15-19). Justeru itu hanya Islam (ajaran yang disampaikan oleh Nabi Muhammad adalah yang benar dan diterima oleh Allah s.w.t (3:19 \& 85). 


\section{Vol. 1: (June.) 2012}

Walaupun dalam al-Quran tetap menyebut dan mengiktiraf kepelbagaian rupa bangsa dan etnik sebagai lambang perpaduan dan kerjasama manusia (49:13). Tetapi dalam hal ini, Islam (melalui penjelasan al-Quran) hanya mengiktiraf kepelbagaian agama bukan kepada kesatuan agama. Ini kerana terdapat juga ayat al-Quran yang menjelaskan perbezaan antara umat Islam dan bukan Islam seperti firman Allah (16:36) yang menjelaskan bahawa semua umat menerima Nabi Muhammad namun terdapat di kalangan umat-umat tersebut yang menerima ajaran Nabi Muhammad dan terdapat sebahagiannya yang menolak, seterusnya dalam firman-firman Allah (3:64-66; 2:137 \& 68:8-9). Malah hal ini turut diperkukuhkan lagi dengan adanya penegasan dan tuntutan kepada nabi Muhammad s.a.w dan umat Islam untuk berdakwah kepada kaum bukan Islam (nonMuslim) supaya menerima ajaran Islam seperti firman Allah (3:20 \& 110).

\section{References}

Adnan Aslan. 1994. Religious Pluralism in Christian and Islamic Philosophy. Jepun : Japan Society Publications.

al-Attas, Syed Mohd Naquib. 1995. Prolegomena to the Methapysic of Islam. Kuala Lumpur : ISTAC.

al-Faruqi, I.R .1986. Meta religion: towards a critical worlds theology. American Journal of Islamic Social Sciences 3 (1): 13-58.

al-Faruqi, I.R. 1998. Islam and other Faiths. Ataullah Siddiqui (pnyt.). Leicester : The Islamic Foundation.

Hick, J. 2005. Religious pluralism and Islam. The Encyclopedia Religion. Jil. 2. New York: Macmillan Publishing.

Kamus Dewan. 2005. Kuala Lumpur : Dewan Bahasa dan Pustaka.

Lorens Bagus. 1996. Kamus Filsafat. Jakarta : PT Gramedia Pustaka Utama.

Rescher, N. 1993. Pluralism: Against the Demand for Consensus. Oxford : Clanderon Press. 